\title{
Teacher Education as a Viable Tool for National Development
}

\author{
Ani Mercy Ifunanya
}

Departement of Science Education

University of Nigeria, Nsukka-Nigeria

Onyia Comfort Ngozi

Departement of Chemistry,
Enugu State College Of Education (Technical), Enugu-Nigeria

Iketaku Ifeoma Roseline

Department Of Educational Psychology,

Enugu State College of Education (Technical), Enugu-Nigeria

\section{Doi:10.5901/jesr.2013.v3n8p69}

\begin{abstract}
The quality of a nation depends upon the quality of its citizens the quality of its citizens depends not exclusively but in crucial measure upon the quality of education and the quality of education depends more than upon any single factor upon the quality of their teachers. This shows that it is imperative to invest in the preparation of teachers so that the future of the nation is secure. The study reviewed the concept of teacher education, challenges facing the teacher education program which could hinder its contribution to national development; recommendations were made based on the findings of this study.
\end{abstract}

Keywords: Challenge, Competent, Education, Teacher Education, National Development

\section{Introduction}

An educational institution performs a significant function of providing learning experiences to lead their students from the darkness of ignorance to the light of knowledge. The key personnel in the institution who play an important role to bring about this transformation are teachers. As stated by the national council for accreditation of teacher education (NCATE) in 1998, that the teacher is the most important element in any educational program.

It is the teacher who is responsible for the implementation of the educational process at any stage. This shows that it is imperative to invest in the preparation of teachers so that the future of the nation is secure. The importance of competent teachers in the nation's school system can be in no way over emphasized. Unless teachers in service are capable and committed, the education system cannot be a suitable and potential instrument in national development

Teacher education is a broad and comprehensive program which is meant to be involved in every community programs and extensive activities, namely adult education and non formal education programs, literacy and development activities of the society. Teacher education is ever evolving and dynamic. In order to prepare teachers who are competent to face the challenges of the dynamic society, teacher education has to keep abreast of recent developments and trends. The crux of the entire process of teacher education has on its curriculum - design, structure, organization and transaction modes as well as the extent of appropriateness (Kanayo, 2012). One 
potent tool that has been adopted by government in her developmental effort is education. Indeed, the main role of education is national development as has been variously postulated by scholars. The wealth and the power of a nation depend on the successful education of its citizens and in the number of highly talented men and women within the national compass, a nation succeeds in providing superior and divergent education (Aboyi, 1994). He adds "Among the factors necessary for ushering in and consolidating contemporary development the factor of education stands in a class by itself

The national policy of education as the counter piece of national development, the government has at various times packaged and tried different educational programs and systems. Blazing the trail of this respect is the universal primary education (UPE) that started in 1976. There have also been the special educational program - education for gifted children, inclusive education, 6-3-3-4 education system, adult and non formal education, open and distance education, nomadic education teacher education program and recently the universal basic education program though none of these education programs can be tagged unqualified success for various reasons, and none can either be called a woeful failure. For our purposes here in this study, we shall be examining teacher education and its role in national development

Among the many objectives of this study are:

1. To examine the teacher education in the country and its relevance to national development;

2. To determine score of the challenge facing the teacher education program which could hinder its contribution to national development and;

3. To make appropriate recommendations.

\section{Teacher Education}

It is well known fact that the quality and extent of learner achievement are determined primarily by teacher competence, sensitivity and teacher motivation. Teacher education is a program of education, research and training of persons to teach from pre primary to higher educational levels. Teacher education is a program that is related to the development of teacher proficiency and competence that would enable and empower the teacher to meet the requirement of the profession and face the challenges there in (Kanayo, 2012). Teacher education is all the formal and informal activities and experiences that help to qualify a person to assume responsibilities of a member of the educational profession (Orubu, 2003). The researchers view teacher's education as encompassing teaching skills, sound pedagogical theory and professional skills.

Teaching skills include providing training and practice in different techniques, approaches and strategies that would help the teachers to plan and impact instructions, provide appropriate reinforcement and conduct effective assessment. It includes effective classroom management skills, preparation and use of instructional materials and communication skill.

Pedagogical theory includes the philosophical, sociological and psychological considerations that will enable the teacher to have a sound basis for practicing the teaching skills in the classroom

Professional Skills include the techniques, strategies and approaches that will help teachers to grow in the profession and also work towards the growth of the profession. The amalgamation of teaching skill, pedagogical teaching and professional skills will serve to create the right knowledge, altitude and skills in teacher thus promoting holistic development. Teacher education is based on the theory that teachers are made not born. In contrary to the assumption teachers are born not made. Since teaching is considered an art and a science, there is need for teacher education. The focus of teacher preparation had to shift from training to education. If it had to make a positive influence on the quality of curriculum transaction in classrooms 


\section{The Concept of National Development}

National development goes far beyond the acquisition of technological products like computers, cars, planes etc or constructing the most beautiful buildings and architectural wonders nor does it mean having good access road, bridges, airports, dams among others. These are bye products of development. The United Nations first Decade said that development is equal to economic growth plus social change which can be translated at the level of the individual / and the society at large. It includes such important human activities at levels of food and nutrition, employment and poverty, reduction within the frame work of equality, dignity and justice; not merely the economic prescription of per-capital income, gross national products and annual grow rates (Opubor, 1986) concurs. He insists that the basic common denominator for any development is the beneficial change for the change for the individual. He therefore concludes that any national development manning must have their greatest beneficial impact on the rural areas must involve labor intensive project . . . provide a capacity for the neglected majority of the rural Africans to better their lives largely through their own effort (p 186)

The focal point of national development in the above submissions are individual and societal change with such indications as quality food; gainful employment; power reduction within the ambit of such frame work as equality, dignity, social justice and equity. A nation cannot therefore be said to have developed when a significant percent of her population are not literate and there is decay in the country's educational system. National development must therefore route for change in all areas of culture which include the economy, technology and environmental in such a way that the physical and mental abilities of the citizenry are best positioned to achieve beneficial change. This repositioning has to be culturally derived from the internal resources of the country to avoid the perennial problem of Western imposed development paradigms which are promethean and therefore antagonistic to indigenous third world post-colonial development efforts(Betiang, 2005: 20).

\section{Teacher Education and National Development}

Teacher education received strong emphasis in the national policy document because of the belief that no education can rise above the quality of teachers (Balogun, 1991). Thus in the white paper are aims of teacher education are spelt out as follows:

- To help teachers to fit into the social life of the community and the society at large and to enhance their commitment to national objectives.

- To provide teachers with the intellectual and professional backgrounds adequate for their assignment and to make them adaptable to any changing situation not only in the life of their country but in the wider world.

- To produce highly motivated conscientious and efficient classroom for all levels of educational system.

- To encourage further the spirit of enquiring and creativity in the teacher.

- To enhance teachers commitment to the teaching profession.

The policy also required teachers across all the educational levels to be professionally trained with the minimum teaching qualification being the Nigeria Certificate in Education (NCE). All teachers with lesser qualifications were to be assisted to rise to at least the Nigeria Certificate in Education (NCE) level and those who could not would have to leave the service (FGN, 1999). The policy went further to describe some of the conditions of service (such as opportunities for promotion at all levels) to enhance career structure and nationwide harmonization of the condition of service, the establishment of a teachers council to care of accreditation, registration, certification, discipline and regulation guiding the teaching profession. The teacher's council was then to compile the list of registration nationwide.

Amucheazi (1980:9) advices that "certainly for Nigeria to develop truly Nigerians must . . . 
and evolve institutions which will enable the individual find his fulfillment. One such institution that can enable the individual find his fulfillment is education. Education without doubt is at the heart of development. Education develops an individual by equipping him/her both intellectually and vocationally to face the realities of life in the larger society. The United Kingdom Department for Intellectual Development (DFID) has stressed the importance of education in national development in its 2002 annual report thus:

\begin{abstract}
Education is at the heart of development. The countries which made the greatest progress in reducing poverty in recent decades are those which have combined effective and equitable investment in education with sound economic policies. Education enables people to use and extend their capabilities develop skills improve their livelihood and increase their earning potential
\end{abstract}

Amplifying the same view literature has it that education is the single most important distinguishing factor between human and animals. Using building as a paradigm, it points out that because of education, human beings have passed through dwelling in caves to huts, shelter, mud houses and today man uses various kinds of building made of concrete, blocks, bricks, stones, glasses and woods. But there is no education among animals; weaver bird for instance, makes the same kind of nest its ancestors made millions of years ago.

Education has increasingly become important to success of both individuals and nations. Growing evidence demonstrates that among all educational resources, teacher's abilities are especially critical contributions to students' learning and consequently the success of a nation to advance in its economic, social and political spheres (Darling Hammond, 2006). Throughout the world, reform and innovation initiatives by nations have triggered much decision about the structures of teacher education and training programs (Herbert 2001)

If the child is the centre of educational system, teachers are the hub of the educational process. For it is upon their number, their education and training their quality and devotion to duty, their effectiveness and efficiency and their competence and their productivity depend on the effectiveness, the capability and the possibilities of the entire educational system and enterprise. The realization of the potentialities of organized education as a veritable instrument for change and national development depends largely on the teachers. Excellent educational policies are meaningless unless there are equally excellent teachers to see to their realization. Various governments may vote sufficient funds as enabling resource for education, adequate materials resources may be procured, but unless the teachers are properly prepared and positively motivated, little productivity will occur. The enabling resources will wasted, the material resources will gather dust and decay and little productive will take place. The researchers maintained that for a developing nation like Nigeria, teachers are the most crucial, critical, vital and strategic professional body for national development.

\title{
5. Challenges
}

The following have been articulated as challenges and possible solutions to enhance teacher education in Nigeria.

\subsection{Inadequate Remuneration of Teachers}

This is particularly a vexed issue, because teachers are the best paid workers in Switzerland and some other developing countries of the world. A teacher is better paid in Togo, Ghana, Uganda, etc, than in Nigeria. Evidently, teaching is not considered attractive in this country, because of the attendant neglect and poor remuneration. Adequate incentive and motivation are required to put practitioners on a proper pedestal. 


\subsection{Recruitment and Training of Teachers}

The method of recruitment of people into teaching profession and their subsequent training skills lack seriousness and vision. School dropouts still find their way into teaching, thus turning teacher training institutions into a dumping ground for those who could not make headway elsewhere. The successful implementation of any nation's educational policy depends to a large extent on the quality and quantity of its teaching force. Dunces should no longer be allowed into the noble profession and government should recruit only trained and qualified teachers into educational system.

\subsection{Poor Teaching and Learning Facilities}

If teacher education should yield great results, then adequate provision of facilities and infrastructure must be boosted by all stakeholders in the teaching profession. It is not unusual to see student-teachers having their training under tree, due to lack of adequate classrooms (Ofoejebe, 2006).

\subsection{Inadequate Professional Development of Teachers}

There is no massive investment in the professional development of teachers and this leads to the raise of quacks and incompetent teachers in the field. There should be massive investment in the professional development of teachers, to ensure that only the professionals are in the field. Any more waste of time in the full professionalization of teaching is not in the interest of our future generation. The quality of education will definitely improve drastically, when this is done.

\subsection{Curricular Problems}

In the colonial era the schools curricular undermined the Nigeria indigenous culture and our integrity and rather enslaved the students and products of the school system with alien ideals. Sadly the effect has injured on even after a national policy and indeed two decades after that policy. The reasons for this statement range from socio- economic through poverty of spirit and values, dependency in the language of learning and communication, to stock ignorance of the teachers. Teachers can only be effective agents of change if they have the wherewithal in terms of knowledge and resources.

\subsection{Teacher-Related Problems}

Many teachers took teaching as a last resort having been rejected as misfit in the other professions. Due to acute shortage of teachers, mediocrity has stepped in to the extent that teachers now teach subjects other than that which they are specialists in. Teacher education has had to contend with pedagogy problems of making effective classes from the situation in the school for so long. Professionalization of teaching and a national registration for teachers will help minimize teacher related problems

\subsection{Economic Problem}

The economic down turn caused by the glut in the oil market since the early 1980s has not helped matters for teacher education, indeed for education generally and all over the country. The Nigerian leaders who had been in power in the 1960s and who had no value for education stole and hoarded the little money in the treasury and misappropriated whatever little was left for education. This vicious attitude as reported in Ojerinde (1967), the military high-handedness and 
unconcealed contempt for the teachers led the military government of 1972 to send university teacher packing out of their quarters within a few hours of the notice because of industrial disharmony over poor wages and unfavorable work conditions.

\section{Conclusion}

The paper examined teacher education, its relevance to national development and the challenges facing the teacher education program that mar its contribution to national development. Attention has been drawn to the importance of teacher education for the development of a nation, capable, dedicated, competent, effective and efficient teachers are indispensible for our success and progress since no nation can rise above its educational system and it teachers.

\section{Recommendations}

The following recommendation are made based on the research findings

1. The government should promptly pay teachers their salaries, allowances and promote them as and when it is due

2. Workshops and seminars should be organized for teachers in different subject areas at least once in a term

3. Teachers should be strictly supervised to assure that effective teaching and learning is taking place

4. Government should recruit only qualified teachers and the unqualified and quack teachers should be identified and flushed out of the system

\section{References}

Aboyi, E. A (1997) Financing technical Education in Nigeria. Issues and trends: A paper presented the national conference of the school of Vocational and Technical Education OJ U, 9-11 July

Amuchaezi, E C (1980). The problem of National Development: social sciences Enugu fourth dimension publishers

Darling Hammond, L (2001). The challenges of staffing on school Education leadership 58(8) pp12-17

Darling Hammond L. (1983). Teacher Education in organizational content. A review of educational research, 53 pp 285-328

Balogun J.O (1991). Teacher Education in Nigeria Benin: NERA

Betiang I (2005). Public broadcasting and National development. NBC News 6(4). DFID Annual report 2002

Federal Republic of Nigeria (2004). National policy on Education Lagos NERDC press

Herbert F.M (2001). Teachers as the Agents of change Educational leadership 50/7 pp 12-17

Kanayo V.A (2012). Preparing teachers for a changing world. Unpublished seminar paper Imo state university Owerri

NCATE (1998). The national council for accreditation of Teacher Education. In Trachtman (1996). Professional Development of school study. Washington D.C

Ofoebge W (2006). The place of teacher. Education in man power development in Nigeria in Maduwewesi J.E \&Eya (EDS). Perspective in Teacher Education. Onitsha: west and Solomon Publishing Co Ltd

Opubor A (1986). Mass communication and modern Development in Nigeria. A book of readings. Enugu: Fourth Dimension publishers 